Proceedings

\title{
Comparative Analysis of Thermal Performance between Courtyards in Mediterranean Climate ${ }^{\dagger}$
}

\author{
Victoria Patricia López-Cabeza, Carmen Galán-Marín *, Carlos Rivera-Gómez, \\ Jorge Roa-Fernández and J. M. Borrego-Baena \\ Departamento de Construcciones Arquitectónicas 1, Escuela Técnica Superior de Arquitectura, \\ Universidad de Sevilla, Avda. Reina Mercedes, 2, 41012 Seville, Spain; vlopez7@us.es (V.P.L.-C.); \\ crivera@us.es (C.R.-G.); jroa@us.es (J.R.-F.); jborregobaena@gmail.com (J.M.B.-B.) \\ * Correspondence: cgalan@us.es; Tel.: +34-954-556-591 \\ + Presented at the Economy, Sustainable Development and Energy International Conference (ESDEIC) 2018, \\ Edinburgh, Scotland, UK, 25-27 June 2018.
}

Published: 30 October 2018

\begin{abstract}
This paper analyzes the thermal performance of three courtyards located in Dos Hermanas (Seville, Spain) simultaneously monitored during five days in the hot period of the year, from 4 June to 9 June. The results show a significant tempering effect in all the courtyards, recording a maximum outdoor-indoor temperature difference up to $11{ }^{\circ} \mathrm{C}$ in the courtyard with the best performance and $7{ }^{\circ} \mathrm{C}$ in the less favorable one. It is confirmed that deep courtyards perform better, and shadows elements such as vegetation also improve the results, creating a good opportunity to use these elements to easily enhance the performance of existing courtyards.
\end{abstract}

Keywords: inner courtyards; patio; Mediterranean climate

\section{Introduction}

The courtyard as an effective passive cooling system takes special relevance in the present situation of climate change accelerated by the high energy consumption [1]. The heat island effect in cities may be mitigated by their own morphology and, accordingly, courtyards are especially relevant in warmer climates such as the Mediterranean due to its proven cooling effect [2]. This effect of the courtyard has been traditionally known and used in warm climates vernacular architecture widespread all over the world [3]. Thermodynamic effects that explain the behavior of the courtyard are affected by many factors such as geometry, vegetation, water or wind among other conditions.

The aim of this study is the comparison of the performance of three different courtyards under the same climatic conditions to analyze the scope of the benefits of the courtyard regarding different factors such as geometry, shadow elements or vegetation.

\section{Materials and Methods}

In this study, the geometric description of the courtyards is based on their Aspect Ratio, which is a value previously described by Hall [4] that relates the height and the width as follows:

$$
\mathrm{AR}=\mathrm{h}_{\max } / \mathrm{W}
$$

where $h_{\max }=$ maximum height of the courtyard and $\mathrm{W}=$ width of the courtyard.

\subsection{Courtyard Description}

For this study, three courtyards of different geometries and proportions were simultaneously monitored during a whole week in Dos Hermanas (Spain 37 $17^{\prime} 01^{\prime \prime} \mathrm{N} 5^{\circ} 55^{\prime} 20^{\prime \prime} \mathrm{W}$, elevation $42 \mathrm{~m}$ a.s.l). 
Dos Hermanas is characterized by the highest summer severity in Spain according to the climate classification established in the Spanish Building codes with maximum mean temperatures of $36^{\circ} \mathrm{C}$ [5]. To select the courtyards for this study, different sizes and geometries have been chosen to represent the variety of typical courtyards inside the buildings in our cities. The three courtyards selected are as follow. Their dimensions are specified in Figure 1:

- Case 1. Residential: This courtyard belongs to a five-story building in an area of high compactness but low edifications. The block has several courtyards. The courtyards of the building are deep and their main functions is providing light and ventilation to the inner rooms. The AR of the courtyard is 4.1 and 1.7 in each direction. The depth of the courtyard prevents the solar radiation reaching the lower part of the walls of the courtyard. The coating of all the wall surfaces is white cement mortar and there are several small windows.

- Case 2. School. The building is organized around the courtyard which is surrounded by a closed gallery that gives access to the classrooms. The AR is 0.8 and 1.3 in each direction. The most characterizing element of the courtyard is the vegetation that partially protects the surfaces from direct solar radiation. The walls are covered with cement mortar painted in white color.

- Case 3. Residential. In a similar neighborhood of the first case, this four-story building has three inner courtyards which are larger than the other cases. The AR is similar to case two, 0.8 and 1.4in each direction. There is a variety of wall finishes, two of them are made of cream color stone, another one is red painted cement mortar and the last one is a curtain wall.

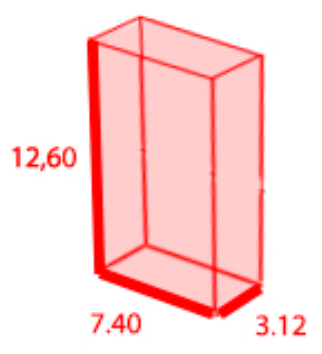

(a)

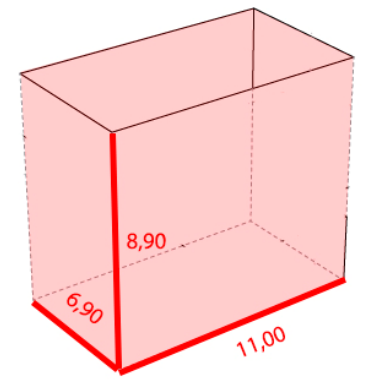

(b)

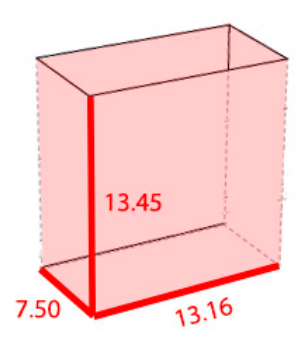

(c)

Figure 1. Scheme and dimensions of the studied courtyards. (a) Case 1. (b) Case 2. (c) Case 3.

\subsection{Monitoring}

The monitoring campaign was carried out during a week between the fourth and the ninth of June, the period of the year when the effect of the courtyards is expected to be higher due to the high temperatures and low humidity. Temperature inside and outside the courtyards has been measured, as well as humidity and wind speed. For the exterior conditions, a meteorological station model PCEFWS 20 has been placed in the roof of the Case 3. Inside the courtyard, air temperature and humidity have been recorded by sensors model TESTO $174 \mathrm{H}$ in the lower level, and air temperature by sensors TESTO $174 \mathrm{~T}$ in two higher levels of the courtyards. A total number of six sensors were placed in each courtyard, protected with insulating material shields to prevent overheating due of solar radiation.

\section{Results}

Figure 2 shows the outdoor temperature and wind speed recorded in the two most representative days of the field campaign. Maximum outer air temperatures ranged between 33-40 ${ }^{\circ} \mathrm{C}$ during those days and minimum at night registered $17-21^{\circ} \mathrm{C}$. The wind recorded during these days was always below $8 \mathrm{~km} / \mathrm{h}$ which was considered not significant to have an important influence inside the courtyards. The figure also shows the mean temperature recorded in each courtyard.

Temperatures recorded inside the courtyards are clearly lower than those in the outside, as expected regarding previous research, the difference being variable depending on the configuration of each courtyard. The courtyard that shows a better performance during the day is Case 1 . The 
difference between outdoor temperature and indoor temperature reaches $11^{\circ} \mathrm{C}$ at $19.00 \mathrm{~h} 7$ June. However, at night hours, the courtyard suffers from overheating, being the indoor temperature higher than in the outside. All these results are explained by the fact that this courtyard has the higher AR. The solar radiation does not reach the lower surfaces of the courtyard and the air temperature remains cooler during the day but, at night, the accumulated heat of the day is not easily loosed because the depth does not help the creation of air flows inside the courtyard.

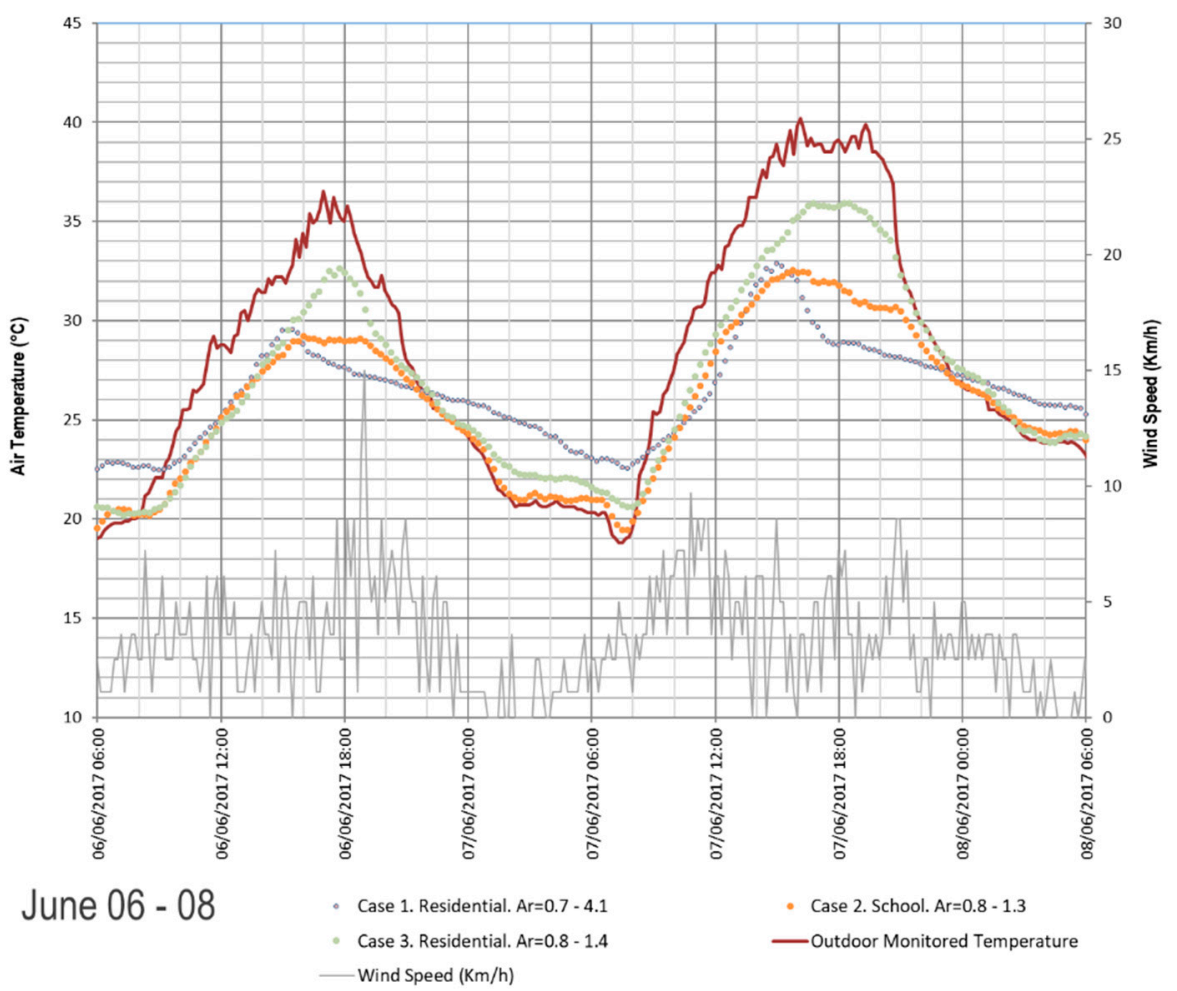

Figure 2. Air Temperature and Wind Speed in courtyards and outside from 6th to 8th June.

Case 2 also shows a good performance during the day. Although it is not as deep as Case 1 and the AR is lower, the temperatures inside the courtyard never rise above $33^{\circ} \mathrm{C}$ when it is at its highest outdoor temperature, creating a microclimate inside that is up to $8.5^{\circ} \mathrm{C}$ cooler. The vegetation provides shadow during the early afternoon, which also improves performance. During the nights, the low aspect ratio allows the courtyard to ventilate and prevent overheating.

The courtyard of Case 3, even though its AR is similar to Case 2, does not perform as well as it. The reason seems to be that it does not have shading elements. However, the microclimate of the courtyard still produces lower temperatures than the outside, resulting in a thermal difference up to $7^{\circ} \mathrm{C}$, which still might mean an important contribution to the thermal efficiency of the building.

Figure 3 shows the temperature difference between the outdoor and each of the courtyards. It can be seen Case 1 presenting a higher thermal leap in the hotter days, followed by Case 2 and Case 3 displaying the lowest difference. It is interesting to notice how in cooler days, as 6 June, when the tempering effect is not so significant, the performance of the three courtyards becomes similar, reaching the same thermal leap although at different hours. 


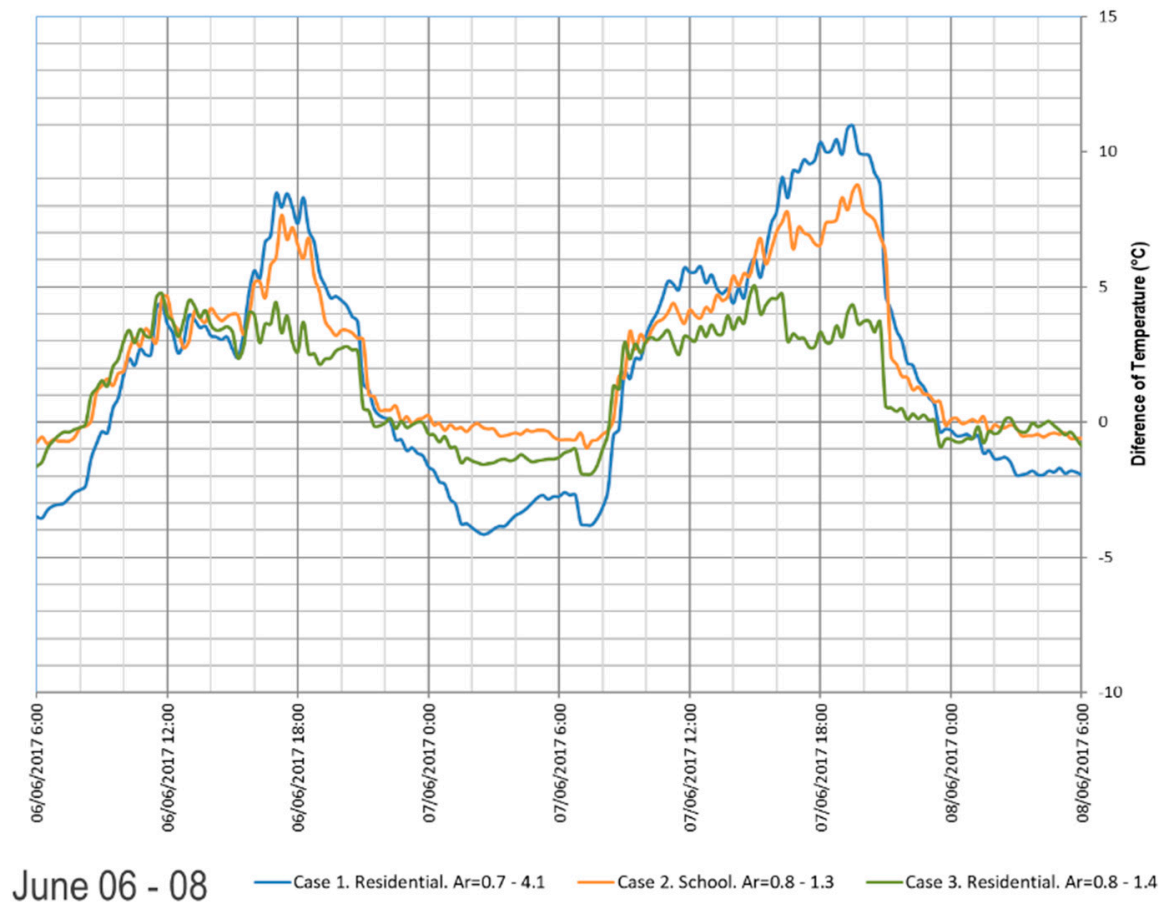

Figure 3. Outdoor-Courtyard Temperature Difference from 6th to 8th June.

\section{Conclusions}

Geometry is an important factor regarding the performance of the courtyard. Besides, this study suggests that other factors, such as the presence of vegetation or shading elements can improve the benefits of a courtyard whose geometry may not be ideal from a previous analysis, as it seems to occur in the Case 2, contrasting it with Case 3. This is interesting because it opens a research line about the possibility of refurbishment of existing courtyards to boost their performance as passive cooling elements.

Our study has proven the temperature in the interior of a courtyard is cooler than outside in warm climates and helps to prevent overheating. The keys of the thermodynamic behavior of the courtyards are based on physical phenomena. The most determining factors in the thermal behavior of the courtyards are the depth, sunlight, air currents and the presence of vegetation and shading elements. With appropriate proportions depending on the climate and combined with natural ventilation and shading or vegetation elements, courtyards can very favorably contribute to efficient building design.

Author Contributions: C.G.-M. and C.R.-G. conceived and designed the experiments; J.M.B.-B. performed the experiments; C.G.-M., V.P.L.-C. and J.R.-F. analyzed the data; V.P.L.-C. and C.G.-M. wrote the paper.

Acknowledgments: The authors wish to acknowledge the IUACC "Instituto Universitario de Arquitectura y Ciencias de la Construcción" for the necessary support to develop this research. This work has been funded by the National Government of Spain Research Project MTM2015-64577-C2-2-R. The authors also want to thank AEMET (State Meteorological Agency. Spanish Government for the data supplied.

Conflicts of Interest: The authors declare no conflict of interest. The founding sponsors had no role in the design of the study; in the collection, analyses, or interpretation of data; in the writing of the manuscript, and in the decision to publish the results. 


\section{References}

1. Stocker, T.F.; Dahe, Q.; Plattner, G.-K.; Tignor, M.; Allen, S.K.; Boschung, J.; Nauels, A.; Xia, Y.; Bex, V.; Midgley, P.M. Climate Change 2013: The Physical Science Basis. Contribution of Working Group I to the Fifth Assessment Report of the Intergovernmental Panel on Climate Change; Technical Summary; Cambridge University Press: Cambridge, UK; New York, NY, USA, 2013; pp. 33-115, doi:10.1017/CBO9781107415324.005.

2. Al-Hemiddi, N.A.; Al-Saud, K.A.M. The effect of a ventilated interior courtyard on the thermal performance of a house in a hot-arid region. Renew Energy 2001, 24, 581-595. doi:10.1016/S09601481(01)00045-3.

3. Taleghani, M.; Tenpierik, M.; van den Dobbelsteen, A. Environmental impact of courtyards-A review and comparison of residential courtyard buildings design in different climates. J. Green Build. 2012, 7, 113-136, doi:10.3992/jgb.7.2.113.

4. Hall, D.J.; Walker, S.; Spanton, A.M. Dispersion from courtyards and other enclosed spaces. Atmos. Environ. 1999, 33, 1187-1203, doi:10.1016/S1352-2310(98)00284-2.

5. Resúmenes Climatológicos-España-Anuales-Agencia Estatal de Meteorología-AEMET. Gobierno de España. Available online: http://www.aemet.es/es/serviciosclimaticos/vigilancia_clima/resumenes?w=0\& datos=2 (accessed on 21 March 2018).

(C) 2018 by the authors. Licensee MDPI, Basel, Switzerland. This article is an open access article distributed under the terms and conditions of the Creative Commons Attribution (CC BY) license (http://creativecommons.org/licenses/by/4.0/). 